\title{
FREIRE, Paulo. Pedagogia da autonomia: saberes necessários à prática educativa. 25 ed. São Paulo. Paz e Terra, 1996. p.166 (Coleção leitura)
}

Neste título, o professor Paulo Freire nos ensina a ensinar partindo do ser professor. Numa linguagem acessível e didaticamente clara, ele reflete sobre saberes necessários à prática educativa - crítica fundamentada numa ética pedagógica e numa visão de mundo alicerçada em rigorosidade, pesquisa, criticidade, risco, humildade, bom senso, tolerância, alegria, curiosidade, esperança, competência, generosidade, disponibilidade, na base da esperança. Nesta obra encontra-se a necessária pedagogia da autonomia, autonomia que faz parte da própria natureza educativa; sem ela não há ensino nem aprendizagem. Segundo a professora Ms Edina Castro de Oliveira, "As ideias retomadas nesta obra resgatam de forma atualizada, leve, criativa, provocativa, corajosa e esperançosa, questões que no dia a dia do professor continuam a instigar o conflito e o debate entre os educadores e as educadoras"(p. 10), então as primeiras Palavras Escritas pelo autor enfocam bastante essa ideia do texto escrita pela professora Edina de Oliveira. Ainda nas Primeiras Palavras, o autor explica que a questão da formação do professor ao lado da reflexão sobre a prática da educação progressiva em favor da liberdade do ser dos alunos é a temática central desta obra. Paulo Freire mostra também que este é um livro esperançoso, otimista, porém não é feito de ingenuidade ou de otimismo falso e de esperança vã.

O autor começa a nos deixar claro que, embora seja do seu interesse central considerar neste texto saberes que lhe parecem indispensáveis para a prática de educadores críticos, progressistas, alguns destes também são de muita importância a educadores conservadores. No decorrer da leitura, vamos descobrindo a descrição do texto ou capítulo lido se encaixa no tipo conservador ou progressista. O autor está convicto da importância de uma reflexão a respeito de uma formação docente e a prática educativo - crítica.

Não há docência sem discência, "quem ensina aprende ao ensinar, e quem aprende ensina ao aprender, quem ensina, ensi-

Marlon Messias Santana Cruz Professor da Rede Municipal de Ensino em Janaúba-MG. marlonmessias@hotmail.com 
na alguma coisa a alguém"(p. 25). Quando Paulo Freire explana que "Ensinar exige rigorosidade metódica"(p. 28) nos mostra que "O educador democrático não pode negar-se o dever de, na sua prática docente, reforçar a capacidade crítica do educando, sua curiosidade, sua insubmissão..."(p. 28) completa com a ideia de que uma das tarefas primordiais do educador é trabalhar com seus educandos a rigorosidade metódica com que devem se aproximar aos conhecimentos adquiridos. O autor nos mostra também que ensinar exige pesquisa e completa explanando "não há ensino sem pesquisa e pesquisa sem ensino"(p. 32). O professor enquanto ensina tem que continuar buscando, re-procurando, o professor tem que indagar e se indagar. Pensar certo, do ponto de vista do professor, tanto implica o respeito ao senso comum no processo de sua necessária superação, quanto o respeito e o estimulo à capacidade criadora do educando. O educador quando atua tem que ter respeito ao saberes do aluno, respeito aos saberes socialmente consumidos na convivência social dos alunos. E a sociedade mudaria a partir da intervenção da escola na sociedade. "Por que não aproveitar a experiência que tem de viver em áreas da cidade da cidade descuidados pelo poder público para discutir, por exemplo, a poluição dos riachos e dos córregos e os baixos níveis de bem estar das populações, os lixões e os riscos que oferecem a saúde das gentes" (p. 33). Esta citação completa com clareza a opinião de aproveitar a convivência social dos seus alunos. Por isso mesmo pensar certo coloca ao professor e ainda mais amplamente a escola, o dever de não só respeitar os saberes com que os educandos chegam a ela, saberes socialmente construídos na prática comunitária. Paulo Freire faz esta colocação quando mostra neste livro que "ensinar exige respeito aos saberes dos educandos".

O professor, assim como o aluno, também é mundo pela curiosidade. Ela é a mola propulsora do aprendizado e do ensino do educador, da construção e produção de conhecimentos. Proporciona um diálogo entre o professor e o aluno, mas este diálogo não pode ser um simples vai-e-vem de perguntas, momentos reflexivos devem existir neste diálogo. Como manifesto presente em experiências de vida de professores, a curiosidade do homem vem sendo, ao logo da história, socialmente construída e reconstruída. É preciso também tomar cuidado com a relação de autoridade relacionada com a liberdade, sempre ameaçadas pela

168 R. Faced, Salvador, n.13, p.163-166, jan./jun. 2008 
prática do autoritarismo e da licenciosidade, prática esta que pode acabar levando o educador a não educar. A necessidade da ingenuidade dar um passo para a criticidade, não deve ser feita a distância de uma rígida formação ética ao lado da estética. "decência e boniteza de mãos dadas". O professor tem que ser seguro, competente e generoso, atitudes estas que exigem esforço e moralidade "Educar é substantivamente formar" (p. 37).

Antes de ser professor, este tem que ser um educador e para isso tem que agir de forma digna dos seus conceitos e interesses, pois não pode esquecer que são formadores de opinião; o exemplo tem que partir deste. O educador não deve falar "de cima para baixo", achar que é o dono da verdade. Um educador não deve falar para os educandos, e sim com os educandos, isso só é possível quando o educador sabe escutar. Porém, o escutar não deve ser passivamente, este deve é uma boa forma de se fazer questionamentos sobre o que está sendo exposto, de defender uma opinião própria. isso pode ser refletido numa maneira crítica e justa de avaliação. "Ao produzir o conhecimento novo supera outro que antes foi novo e se fez velho e se dispõe a ser ultrapassado por outro amanhã". Professor tem que ter sua opinião política sem ser prosélito para assim evitar formas de discriminação, pensar certo e diálogo e não polêmico.

"Ensinar não é transferir conhecimento". O autor prossegue com base nesta afirmação. O professor não pode somente transferir conhecimento, devendo haver uma troca de ensinamentos e aprendizagens entre educador e educando. O professor deve estar aberto aos questionamentos e dificuldades dos alunos. Entretanto, se o aluno foi submetido a um falso ensinar, isso não vai significar que ele, através da sua capacidade de arriscar e questionar, não possa superar este problema. "Saber que ensinar não é transferir conhecimento, mas criar as possibilidades para a sua própria produção" (p. 52), o professor tem que ser aberto a questões, indagações, à curiosidade, um ser crítico e questionador e o que devemos formar. Quando o professor discute determinada teoria, ele e os alunos têm que estar comprometidos nesta teoria.

Um professor crítico é responsável por desenvolver esta criticidade em seus educandos, e está proposto à mudança, à aceitação do diferente; o autor nos mostra que "Ensinar exige consciência do inacabamento", o corpo humano é dotado de consciência, captador, apreendedor, transformador, criador de beleza e não 
um espaço vazio a ser abarrotado por conteúdos, não deve haver discriminação, pois esta prática fere a dignidade do ser humano e não se aplica a democracia "como professor crítico, sou um 'aventureiro' responsável, predisposto à mudança, à aceitação do diferente. Nada do que experimentei em minha atividade docente deve necessariamente repetir-se"(p. 55). Somos seres capazes de intervir no mundo, de comparar, de ajuizar, de decidir, de dignificantes testemunhos, mas também de impensáveis exemplos de beleza e de indignidade. O educador tem que ter consciência de que ele é um ser altamente transformador, e não apenas objeto, mas sujeito também da história. O professor tem que ter a capacidade de politizar de trabalhar os elementos da cultura, de idealizar a formação, fundar a educação como processo permanente. "gosto de ser gente porque, inacabado, sei que sou um ser condicionado, mas consciente do inacabamento, sei que posso ir mais além dele. Esta é a diferença profunda entre o ser condicionado e o ser determinado" (p. 59).

O professor não pode, nem deve, limitar a liberdade do aluno, não pode tirar o direito do aluno de ser curioso e inquieto e desta forma a ética aparece no contexto deste professor, ética esta que está em respeitar a autonomia e a dignidade de cada um. É essencial que o professor mantenha sua ética respeitando a individualidade de cada aluno. "o respeito a autonomia e a dignidade de cada um é imperativo ético e não um favor que podemos ou não conceder uns aos outros".(p. 66) O professor tem como necessidade respeitar a autonomia e a identidade de cada educando.

"Ensinar exige bom senso"; o professor tem que estar consciente de que suas atitudes podem influenciar profundamente a vida de um aluno, positivamente ou negativamente, este professor deve estar sempre avaliando a sua prática pedagógica. O bom senso propõe para o professor uma reflexão na relação professor/aluno; para adquirir bom senso é necessário exercitá-lo, de forma prática, a nossa capacidade de indagar, de comparar, de duvidar, de aferir tanto mais curioso quanto mais crítico. "O exercício do bom senso, como o qual só temos o que ganhar, se faz no 'corpo' da curiosidade" (p. 69). O bom senso atua como um guia intelectual, demonstra a realidade, é objetivo, concreto, dá suporte para diferenciar e comparar.

É dever do educador lutar pelo seu direito, valorizando assim sua autoridade docente como também respeitando os 
educandos, o educado deve lutar contra o desrespeito do poder público com a educação, e para que consiga este valor é necessário procurar evitar uma prática simples e afetiva. As políticas públicas deveriam valorizar a formação permanente dos professores.

O educador deve despertar no aluno a importância da curiosidade, a curiosidade domada leva o aluno a memorizar o objetivo e não ao aprendizado real. Para o aluno produzir o conhecimento, ele deve estar inserido no exercício da curiosidade, na capacidade crítica do objetivo, de observá-lo. É necessário que professor e aluno mantenham um diálogo aberto, que sejam curiosos, indagadores e não passivos enquanto fala ou ouve.

Ensinar é uma especificidade humana, o professor deve ser seguro de si, sendo esta a sua maior autoridade, sua segurança e firmeza nas ações e decisões e respeito nas discussões; esta segurança mostra sua autoridade, "creio que uma das qualidades essenciais que a autoridade docente democrática deve revelar em suas relações com as liberdades dos alunos é a segurança em si mesmo" (p. 102). Além da segurança, o professor precisa ser competente, esta competência torna-se necessária à autoridade docente. Esta competência esta ligada ao professor que estuda, que está atento ao que acontece dentro e fora da escola; portanto, a incompetência desqualifica a autonomia. O professor não deve ser autoritário, sempre humilde para assim respeitar os alunos. A arrogância é que faz com que o professor tenha que agir incondicionalmente com seus alunos; o clima de respeito é resultante das relações justas, sérias, humildes, generosas, autênticas. O caráter formador do espaço pedagógico, a autoridade, acaba por restringir a criatividade do educando. Entretanto, a autoridade coerente, democrática é posta na liberdade, pois com autonomia a liberdade ocupa espaço da dependência.

O fundamental na aprendizagem de qualquer conteúdo é a construção das responsabilidades e da liberdade que se assume, mas não se deve separar o ensino dos conteúdos da formação ética dos professores e educandos, pois "Ensinar exige compreender que a educação é uma forma de intervenção no mundo". Prática e teoria, autoridade e liberdade, ignorância e saber, respeito ao professor e aos alunos, ensinar e aprender estes conceitos não devem estar separadoss uns dos outros. O respeito que os professores devem aos alunos dificilmente se cumpre. O profes- 
sor tem que se expor politicamente, ser humilde o bastante para revelar quando não sabe sobre determinado assunto, mas buscar respostas para suprir a necessidade dos alunos. A opinião do aluno é de extrema importância para o crescimento do professor, a ideologia dominante hoje neutraliza esta relação.

Paulo Freire é completamente contra a transgressão ética e crítica também o conformismo; cita ainda que o professor tem que ser coerente na tomada de decisões e é contra a neutralidade. Pedagogia da autonomia serve como fonte de conhecimentos para educadores em geral. Relacionando a obra com a teoria marxista, pode-se dizer que nesta ideia ao conceber a existência de contradições raciais que consistiam na existência e convivência de situações opostas, como a dicotomia dominante e dominado, patrão e empregado, progresso e atraso, riqueza e pobreza, Pedagogia da autonomia acaba por contribuir para a fundamentação de uma teoria social muito abrangente ao contemplar elementos dialéticos, elementos da prática política, como a educação. A constatação e a busca de uma educação que revela as estruturas políticas pode mostrar a alienação das massas. 